\title{
PENGARUH LAMA PERENDAMAN TERHADAP KANDUNGAN SIANIDA PADA UBI KAYU BERACUN TAHUN 2015
}

\author{
Sri Bulan Nasution \\ Jurusan Analis Poltekkes Medan
}

\begin{abstract}
Abstrak
Ubi kayu (Manihot esculenta) merupakan tanaman pangan berupa perdu dengan nama lain ketela pohon juga singkong.Ubi kayu merupakan sumber karbohidrat yang paling penting setelah beras.Selain karbohidrat,ubi kayu juga mengandung asam sianida.Ada jenis ubi kayu yang kadar sianidanya tinggi, dengan ciri-ciri ukuran lebih besar dari singkong biasa.Asam Sianida pada ubi kayu dapat menimbulkan rasa pahit, menandakan bahwa kadar asam sianida pada ubi kayu itu cukup tinggi dan apabila ubi kayu itu dikonsumsi, mengakibatkan keracunan dan dapat berujung pada kematian dengan gejala awal seperti mual, muntah, pusing, sukar bernafas, detak jantung cepat, juga kejang-kejang. Dari latar belakang diatas di lakukan penelitian pengaruh perendaman terhadap sianida pada ubi kayu beracun yang bertujuan untuk mengetahui berapa kadar yang turun apabila dilakukan perendaman. Penelitian ini dilaksanakan di laboratorium kesehatan provinsi sumatera utara pada bulan juni 2014. Metode penelitian ini adalah titrasi argentometri.Sampel ubi kayu beracun berumur 7-8 bulan, di ambil pada pagi hari di sekitar kecamatan percut sei tuan. Pemeriksaan dilakukan cara duplo, di dapatkan hasil kadar sianida tertinggi pada perendaman 0 (nol) hari sebesar $81,5 \mathrm{mg} / \mathrm{kg}, \mathrm{kadar}$ sianida terendah pada perendaman 3 hari sebesar 36 $\mathrm{mg} / \mathrm{kg}$. Hasil yang di peroleh menunjukan bahwa kadar sianida pada ubi kayu beracun dapat turun mencapai $55,82 \%$ dengan perlakuan khusus yaitu dengan cara perendaman. Makin besar ubi kayu, kadar sianida makin tinggi. Sarannya agar melakukan perendaman pada ubi kayu sebelum di konsumsi agar rasa pahit berkurang dan dapat di konsumsi.
\end{abstract}

Kata kunci : Ubi Kayu, Sianida, Lama Perendaman

\section{LATAR BELAKANG}

Ubi kayu dikenal juga dengan nama latin Manihot esculenta adalah pohon tahunan dan sub tropika yang berasal dari keluarga Euphorbiaceace dan merupakan tanaman dengan karbohidrat tinggi dan miskin protein. Ubi kayu menghasilkan umbi yang mengandung pati dan pada umbi inilah terdapat racun yang dikenal dengan nama Asam Sianida (HCN).Ubi kayu bersifat tidak tahan lama serta mudah mengalami kerusakan,kerusakan ini disebabkan proses fisiologis dan serangan mikroba. Semakin bertambah tua ubi kayu, maka ubi kayu juga akan makin mengalami kerusakan sehingga meningkatkan kadar asam Sianida.Sianida adalah senyawa kimia yang sangat toksik atau berpotensi menimbulkan efek kematian(Yuningsih, 2009).

Berdasarkan pengamatan penulis, ada tanaman yang disebut singkong gendruwo.Singkong ini berukuran lebih besar dari singkong biasa, batangnya menyerupai pohon tetapi perdu.Umbi, daun juga batang nya berukuran besar maka di katakan singkong gendruwo. Bagian akar disebut juga umbi dengan dagingnya berwarna putih atau kekuning-kuningan bila dalam keadaan segar. Umbinya mengandung air sekitar $60 \%$, pati $25-35 \%$ serta protein, mineral, serat, kalsium, dan fosfat.
Umbi ini juga tidak tahan disimpan lama tanpa perlakuan khusus setelah dipanen kurang lebih selama dua hari. Pada saat itu, singkong telah mengandung racun yang ditandai oleh perubahan warna daging buahnya menjadi biru gelap.Berhati-hatilah terbentuknya warna biru gelap tersebut menunjukan adanya kandungan racun pada singkong secara tidak langsung.Gejala keracunan akut singkong ini diantaranya berupa gangguan saluran cerna seperti mual, muntah, pusing, sukar bernapas atau pernapasan, detak jantung cepat, kulit menjadi kebiruan, kejang-kejang.

Asam Sianida pada ubi kayu dapat menimbulkan rasa pahit, rasa pahit itu menandakan bahwa kadar asam sianida pada ubi kayu itu cukup tinggi dan apabila ubi kayu itu dikonsumsi, maka akan mengakibatkan keracunan bagi konsumen dan dapat berujung pada kematian.Asam sianida sangat berbahaya bagi manusia apalagi racun ini terdapat pada salah satu bahan makanan yang sering dikonsumsi oleh manusia yaitu ubi kayu. Mengingat akan bahayanya bagi manusia. Masalah utama yang muncul adalah besarnya kandungan senyawa glukosida sianogenik di dalam ubi kayu yang memiliki kecendrungan sebagai racun(Ardhiyanto,2013).

Racun adalah setiap bahan/zat yang dalam jumlah relatif kecil bila masuk ke dalam tubuh akan menimbulkan reaksi kimia yang akan menyebabkan 
penyakit atau kematian. Racun juga merupakan suatu zat yang bekerja pada tubuh secara fisiologis yang dalam doksis toksik selalu menyebabkan gangguan fungsi tubuh, hal mana dapat menimbulkan penyakit dan kematian.Masing-masing senyawa sianida mempunyai bentuk dan kecepatan aktif (toksisitas) yang berbeda di dalam tubuh, baik sianida sintetis maupun sianida alami (Yuningsih,2009).

Sianida $(\mathrm{CN})$ dikenal sebagai senyawa racun dan mengganggu kesehatan serta mengurangi bioavailabilitas nutrient di dalam tubuh.Racun ini menghambat sel tubuh mendapatkan oksigen sehingga yang paling terpengaruh adalah jantung dan otak. Kadar sianida yang tinggi dalam darah dapat menyebabkan efek yang berbahaya, seperti jari tangan dan kaki lemah, susah berjalan, pandangan buram, ketulian, dan gangguan pada kelenjar gondok. Sianida termaksud golongan bahan kimia sangat beracun dan reaktif.Racun tersebut dapat terjadi bila sianida terhirup/terserap kulit (Widodo dkk, 2010).

Kandungan asam sianida pada setiap jenis singkong berbeda-beda.Biasanya semakin pahit singkong, semakin tinggi kandungan asam sianidanya. Untuksingkong manis kadar asam sianidanya rendah di bawah $40 \mathrm{mg} / \mathrm{kg}$ umbi adalah relatif aman, tidak membahayakan kesehatan, dan berasa manis. Sedikit saja singkong memiliki rasa pahit, maka singkong tersebut telah mengandung kadar asam sianida di atas $50 \mathrm{mg} / \mathrm{kg}$ umbi segar atau 50-80 mg/kg umbi segar. Sementara itu, singkong menjadi membahayakan kesehatan bahkan dapat mematikan bila kandungan asam sianidanya lebih dari 100 $\mathrm{mg} / \mathrm{kg}$ umbi segar (Suprapti, 2005).

Asam sianida bersifat mudah menguap di udara, terutama pada suhu di atas $25^{\circ} \mathrm{C}$.karena sifat asam sianida yang mudah larut dalam air, Oleh karena itu perendaman sangat diperlukan untuk mengurangi racun asam sianida. Cara lainproses penjemuran pada sinar matahari dapat menguraikan asam sianida sampai $80 \%$. Pengupasan kulit perlu dilakukan karena justru dalam kulit ini terdapat asam sianida dengan konsentrasi mencapai 15 kali lebih besar dari konsentrasi asam sianida di dalam daging umbinya.

Tingkat racun sianida di dalam tubuh seseorang pun ditentukan dari daya

tahan tubuh untuk menoleransi racun tersebut. Bagi anakanak dan orang dewasa yang sedikit mengonsumsi protein dalam makanannya, mereka tergolong sensitif terhadap racun sianida. Karena bagaimanapun juga protein berfungsi membantu dalam proses penguraian racun atau lebih dikenal detoksifikasi. Karena itu, mengonsumsi umbi singkong dan beberapa jenis umbi-umbi lain yang mengandung sianida tetap memperhatikan cara pengolahan untuk menghilangkan racunnya. Memilih jenis singkong manis dan masih segar serta tetap mengonsumsi jenis-jenis makanan lain yang mengandung protein, vitamin, dan mineral.

\section{TINJAUAN PUSTAKA}

\section{A. Ubi Kayu/Singkong (Manihot esculenta)}

Ubi kayu (Manihot esculenta) merupakan tanaman pangan berupa perdu dengan nama lain ketela pohon, singkong, atau kasape. Ubi kayu berasal dari benua Amerika, tepatnya dari negara Brasil.Penyebarannya hampir ke seluruh dunia, antara lain Afrika, Madagaskar, India, dan Tiongkok.Ubi kayu diperkirakan masuk ke Indonesia pada tahun 1852 (Hambali, 2007).

Ubi kayu merupakan jenis umbi yang banyak dikonsumsi masyarakat.Ubi kayu merupakan sumber karbohidrat yang paling penting setelah beras.Ubi kayu mudah tumbuh sekalipun pada tanah kering dan miskin serta tahan terhadap serangan penyakit maupun tumbuhan pengganggu.Tanaman singkong mudah (membudidayakannya) karena perbanyakan tanaman ini umumnya dengan stek batang.Ubi kayu dapat ditanam di dataran rendah sampai dataran tinggi yang kurang dari (1300 m dpl).Tanaman ini membutuhkan udara hangat dengan suhu rata-rata $200^{\circ} \mathrm{C}$ dan curah hujan.Potensi ubi kayu di Indonesia sangat besar (Hambali, 2007).

Adapun unsur gizi yang terdapat dalam tiap $100 \mathrm{~g}$ singkong segar dapat dilihat dalam Tabel.

Tabel 1. Kandungan Gizi dalam Tiap $100 \mathrm{~g}$ Singkong

\begin{tabular}{clcc}
\hline & & \multicolumn{2}{c}{ Dalam 100 g singkong segar } \\
\cline { 3 - 4 } No. & Unsur Gizi & $\begin{array}{c}\text { Singkong } \\
\text { Putih }\end{array}$ & $\begin{array}{c}\text { Singkong } \\
\text { Kuning }\end{array}$ \\
\hline 1. & Kalori (kal) & 146,00 & 157,00 \\
2. & Protein (g) & 1,20 & 0,80 \\
3. & Lemak (g) & 0,30 & 0,30 \\
4. & Karbohidrat (g) & 34,70 & 37,90 \\
5. & Kalsium (mg) & 33,00 & 33,00 \\
6. & Fosfor (mg) & 40,00 & 40,00 \\
7. & Zat Besi (mg) & 0,70 & 0,70 \\
8. & Vitamin A (SI) & 0 & 385,00 \\
9. & Vitamin B1 (mg) & 0,06 & 0,06 \\
10. & Vitamin C (mg) & 30,00 & 30,00 \\
11. & Air (g) & 62,50 & 60,00 \\
12. & Bagian dapat & 75,00 & 75,00 \\
& dimakan (\%) & & \\
\hline
\end{tabular}

Selain kandungan gizi di atas, singkong juga mengandung racun yang dalam jumlah besar cukup berbahaya.Racun singkong yang selama ini kita kenal adalah Asam biru atau Asam sianida.Baik daun maupun umbinya mengandung suatu glikosida sianogenik, artinya suatu ikatan organik yang dapat menghasilkan racun biru atau HCN yang bersifat sangat toksik.http://www.gobookee.org/ebook/

Singkong manis banyak di konsumsi secara langsung atau digunakan untuk jajanan tradisional, misalnya gethuk, sawut, utri (lemet), dan lain-lain. Rasa manis singkong disebabkan oleh kandungan asam sianida yang sangat rendah, hanya sebesar 40mg $\mathrm{HCN} / \mathrm{kg}$ singkong. Ada beberapa jenis singkong manis dan singkong pahit antara lain sebagai berikut. 
Tabel 2. Kandungan HCN dalam Beberapa Jenis Singkong dan Pengaruhnya Terhadap Rasa Umbi Singkong

\begin{tabular}{clccc} 
No. & Jenis/varietas & $\begin{array}{c}\text { Kadar HCN } \\
\text { (mg/kg umbi) }\end{array}$ & $\begin{array}{c}\text { Warna } \\
\text { Umbi }\end{array}$ & Rasa \\
\hline 1 & Gading & 31,9 & Putih & Enak \\
2 & Adira I & 27,5 & Kuning & Enak \\
3 & W-1705 & 10 & Putih & Enak \\
4 & W-1548 & 34 & Putih & Enak \\
5 & Valenca & 39 & - & Enak \\
6 & Mangi & 30 & - & Enak \\
7 & Betawi & 30 & - & Enak \\
8 & Singapura & 60 & - & Enak \\
9 & Basiorao & 80 & - & Agak \\
10 & Adira IV & 68 & Putih & Pahit \\
11 & Muara & 100 & Putih & Pahit \\
12 & Tapikuru & 130 & - & Pahit \\
13 & Bogor & 100 & - & Pahit \\
14 & Adira II & 123,7 & Putih & Pahit \\
15 & SPP & $150-206$ & - & Pahit
\end{tabular}

Sumber: Dirjen Tanaman Pangan ,Departemen Pertanian, Jakarta, 1989

\section{B. Asam Sianida (HCN)}

Asam sianida disebut juga Hidrogen sianida $(\mathrm{HCN})$, biasanya terdapat dalam bentuk gas atau larutan dan terdapat pula dalam bentuk garam-garam alkali seperti potasium sianida.Sifat-sifat HCN murni mempunyai sifat tidak berwarna, mudah menguap pada suhu kamar dan mempunyai bau khas. HCN mempunyai berat molekul yang ringan, sukar terionisasi, mudah berdifusi dan lekas diserap melalui paru-paru, saluran cerna dan kulit.Sianida termaksuk golongan bahan kimia sangat beracun dan reaktif.Reaksi racun tersebut dapat terjadi bila sianida terhirup atau terserap kulit (Widodo dkk, 2010).

Glikosida sianogenetik merupakan senyawa yang terdapat dalam bahan makanan nabati dan secara potensial sangat beracun karena dapat terurai dan mengeluarkan hidrogen sianida.Hidrogen sianida dikeluarkan bila komoditi tersebut dihancurkan, dikunyah, mengalami pengirisan, atau rusak. Glikosida sianogenetik terdapat pada berbagai tanaman dengan nama senyawa yang berbeda seperti amigladin pada biji almonds, aprikot dan apel, dhurin pada biji shorgum, dan linamarin pada singkong. Nama kimia bagi amigladin adalah glukosida benzaldehida sianohidrin; dhurin; glukosida p-hidroksidabenzaldehida sianohidrin; linamarin; glukosida aseton sianohidrin (Winarno, F.G. 2004)

Zat glikosida ini diberi nama linamarin yang berasal dari aseton sianidrin yang bila dihidrolisis akan terurai menjadi glukosa, aseton dan HCN. Rumus molekul linamarin $\mathrm{C} 10 \mathrm{H} 17 \mathrm{O} 6 \mathrm{~N}$ dan mempunyai sifat yang mudah larut dalam air.

HCN dikenal sebagai racun yang mematikan.HCN akan menyerang langsung dan menghambat sistem antar ruang sel, yaitu menghambat system cytochroom oxidase dalam sel-sel, hal ini menyebabkan zat pembakaran (oksigen) tidak dapat beredar ketiap-tiap jaringan sel-sel dalam tubuh. Dengan sistem keracunan ini maka menimbulkan tekanan dari alatalat pernafasan yang menyebabkan kegagalan pernafasan, menghentikan pernafasan dan jika tidak tertolong akan menyebabkan kematian. Bila dicerna, $\mathrm{HCN}$ sangat cepat terserap oleh alat pencernaan masuk ke dalam saluran darah.Tergantung jumlahnya $\mathrm{HCN}$ dapat menyebabkan sakit hingga kematian (dosis yang mematikan 0,5- 3,5 mg HCN/kg berat badan ) (Winarno, F.G. 2004 ).

Ada beberapa cara yang dapat dilakukan untuk mengurangi kandungan $\mathrm{HCN}$ yang terdapat dalam singkong, yaitu dengan cara perendaman, pencucian, perebusan, pengukusan, penggorengan atau pengolahan lain. Dengan adanya pengolahan dimungkinkan dapat mengurangi kadar HCN sehingga bila singkong dikonsumsi tidak akan membahayakan bagi tubuh).

Pengolahan secara tradisional dapat mengurangi/ bahkan menghilangkan kandungan racun.Pada singkong, kulitnya dikupas sebelum diolah, direndam sebelum dimasak dan difermentasi selama beberapa hari. Dengan perlakuan tersebut linamarin banyak yang rusak dan hidrogen sianidanya ikut terbuang keluar sehingga tinggal sekitar 10- 40 mg/kg (Winarno,F.G. 2004).

Asam biru (HCN) dapat larut di dalam air maka untuk menghilangkan asam biru tersebut cara yang paling mudah adalah merendamnya di dalam air pada waktu tertentu.

\section{Skema Kerja

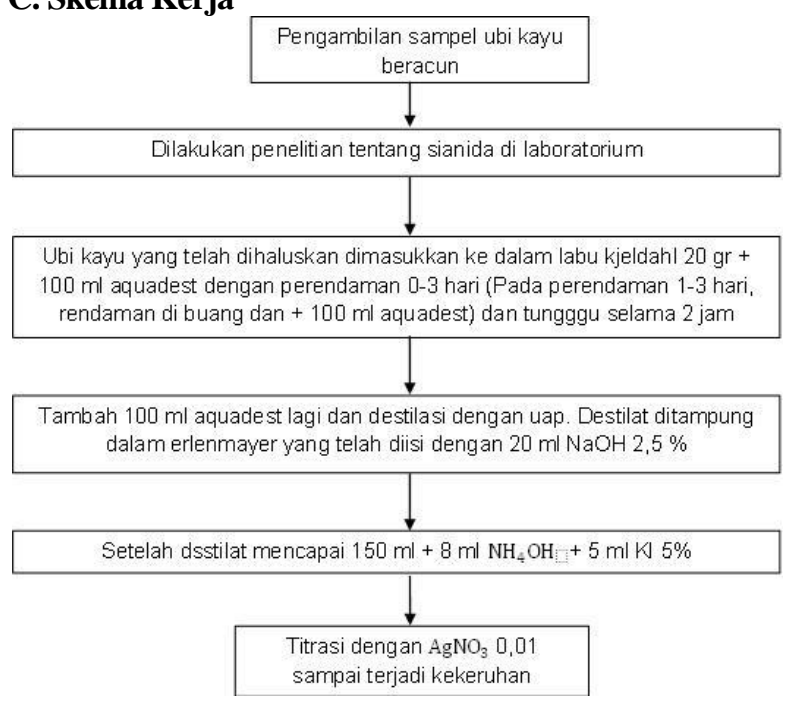

\section{METODE PENELITIAN}

\section{A. Jenis Dan Desain Penelitian}

Jenis penelitian ini adalah penelitian surve yang bersifat deskriptif yang bertujuan untuk mengetahui pengaruh lama perendaman terhadap sianida pada ubi kayu beracun.

\section{B. Lokasi Penelitian Dan Waktu Penelitian}

Penelitian ini akan di laksanakan di Laboratorium Kesehatan Provinsi Sumatra Utara Bagian Kimia toksikologi.Waktu Penelitian di laksanakan bulan April Juni 2015. 


\section{Populasi dan Sampel Penelitian}

Populasi pada penelitian ini adalah ubi kayu beracun yang ditanam di sekitar kecamatan Percut Sei Tuan.Sampel yang di periksa adalah sampel ubi kayu beracun yang berumur sekitar 7-8 bulan.

\section{Jenis dan Cara Pengumpulan Data}

Metode yang dilakukan dalam penelitian ini adalah Eksperimen laboratorium secara kuantitatif metode Titrasi Argentometri.

Alatyang digunakan dalam penelitian ini adalah beaker gelas, gelas ukur, pipet tetes, neraca, sendok, Erlenmeyer tertutup, labu kjeldhal, kompor dapenangas air, aquadest, alat destilasi, buret dan Bahan yang digunakan adalah ubi kayu beracun yang telah di haluskan.

\section{E. Pengolahan Dan Analisa Data}

Data yang diperoleh disajikan dalam bentuk tabel secara deskriftif apakah ada pengaruh lama perendaman terhadap sianida pada ubi kayu beracun.

\section{F. Prosedur kerja}

\section{F.1. Prosedur Pengambilan Sampel}

Sampel ubi kayu beracun diambil pada pagi hari agar di dapatkan ubi yang segar. Lalu ubi kayu di timbang sebanyak $1 \mathrm{~kg}$ dan dikupas juga di haluskan dan di masukan ke dalam wadah yang tertutup.Lalu sampel di bawa ke laboratorium.

Tabel 3. Hasil penelitian Kadar sianida pada ubi kayu beracun.

\begin{tabular}{|c|c|c|c|c|c|c|c|c|}
\hline \multirow[t]{2}{*}{$\begin{array}{l}\text { Kode } \\
\text { Sampel }\end{array}$} & \multirow[t]{2}{*}{$\begin{array}{l}\text { Lama } \\
\text { Perendaman }\end{array}$} & \multicolumn{2}{|c|}{ Berat Sampel (gr) } & \multicolumn{2}{|c|}{$\begin{array}{c}\text { Volume } \\
\text { Pentiter } \\
\text { AgNO }_{3} 0.01 \mathrm{~N}\end{array}$} & \multicolumn{2}{|c|}{$\begin{array}{c}\text { Kadar } \\
\mathrm{HCN} \\
(\mathrm{mg} / \mathrm{kg})\end{array}$} & \multirow[t]{2}{*}{$\begin{array}{c}\text { Kadar } \\
\text { Sebenarnya }\end{array}$} \\
\hline & & B1 & B2 & $\mathrm{V} 1$ & $\mathrm{~V} 2$ & K1 & K2 & \\
\hline A & 0 Hari & 20,2074 & 20,5373 & 6,10 & 6,30 & 81 & 82 & 81,5 \\
\hline B & 1 Hari & 20,1523 & 20,4371 & 4,90 & 4,70 & 65 & 62 & 63,5 \\
\hline C & 2 Hari & 20,3741 & 20,2310 & 3,50 & 3,70 & 46 & 49 & 47,5 \\
\hline D & 3 Hari & 20,4791 & 20,8021 & 2,60 & 3,00 & 34 & 38 & 36 \\
\hline
\end{tabular}

\begin{aligned} \hline Penurunan $= & 81,5 \mathrm{mg}-36 \mathrm{mg} \\ & =45,5 \mathrm{mg} \\$ Maka & $\frac{45,5}{81,5} \times 100 \% \\ & =55,82 \%\end{aligned}$

\section{HASIL DAN PEMBAHASAN}

\section{A. Hasil}

Berdasarkan hasil penelitian yang telah dilakukan maka diperoleh data sebagai berikut :

\section{B. Pembahasan}

Berdasarkan uraian diatas penulis menganalisa kadar sianida pada ubi kayu beracun dengan lama perendaman di dapatkan hasil tertinggi pada sampel A yang kadar sianidanya $81,5 \mathrm{mg} / \mathrm{kg}$ dengan perendaman 0 (nol) hari (2 Jam). Hal ini dikarenakan ubi kayu diperiksa dalam keadaan segar, sehingga kadarnya masih terlalu tinggi. Sedangkan kadar terendah pada sampel D di dapatkan hasil $36 \mathrm{mg} / \mathrm{kg}$ dengan lama perendaman 3 hari. Hal ini di pengaruhi oleh lamanya perendaman pada sampel D sehingga di dapat hasil yang menurun.Dari uraian di atas dapat ditarik kesimpulan bahwa kadar sianida pada ubi kayu beracun dapat turun 55,82 \% kadarnya apabila di lakukan perendaman.

Ubi kayu manis kadar asam sianidanya rendah di bawah $40 \mathrm{mg} / \mathrm{kg}$ umbi adalah relatif aman, tidak membahayakan kesehatan, dan berasa manis. Sedikit saja ubi kayu memiliki rasa pahit, maka ubi kayu tersebut telah mengandung kadar asam sianida di atas $50 \mathrm{mg} / \mathrm{kg}$ umbi segar atau $50-80 \mathrm{mg} / \mathrm{kg}$ umbi segar. Sementara itu, ubi kayu menjadi membahayakan kesehatan bahkan dapat mematikan bila kandungan asam sianidanya lebih dari $100 \mathrm{mg} / \mathrm{kg}$ umbi segar.

Ubi kayu yang kadar sianidanya rendah telah menjadi salah satu kebutuhan pokok bagi masyarakat sampai saat ini, baik yang hidup di pedesaan maupun di perkotaan. Sedangkan ubi kayu yang kadar sianidanya tinggi lebih banyak diambil patinya untuk di olah menjadi tepung, peptisida organik, dan juga dapat sebagai bahan biogas.

\section{KESIMPULAN}

Hasil penelitian secara kualitatif yang dilakukan menunjukan adanya sianida pada ubi kayu beracun di tandai dengan perubahan warna pada kertas pikrat yang berubah warna dari kuning menjadi merah coklat. Dan di lanjutkan secara kuantitatif dengan metode titrasi argentometri di peroleh kadar sianida pada ubi kayu beracun dengan perendaman 0 (nol) hari mencapai 81,5 $\mathrm{mg} / \mathrm{kg}$ dan kadar sianida pada ubi kayu beracun dengan perendaman 3 hari mencapai $36 \mathrm{mg} / \mathrm{kg}$.

Jadi, dari hasil penelitian yang telah di lakukan di Laboratorium Kesehatan Jl. William Iskandar Medan pada bulan Juni 2014 dapat disimpulkan bahwa kadar sianida pada ubi kayu beracun dapat turun mencapai $55,82 \%$ dengan perlakuan khusus yaitu dengan cara perendaman.

\section{SARAN}

1. Kepada masyarakat agar dapat membedakan bahan pangan mana yang layak dikonsumsi dan tidak layak dikonsumsi untuk kesehatan.

2. Lakukan lah perendaman, perebusan juga pengringan yang efektif agar bahan pangan dapat di konsumsi untuk kesehatan.

3. Diperlukan penelitian lebih lanjut untuk penurunan kandungan sianida dengan cara penjemuran pada sinar matahari langsung.

4. Perlu diadakannya penelitian mengenai pengembangan metode penurunan sianida lainnya pada bahan pangan, sehingga ke depannya diharapkan metode penurunan sianida yang lebih optimal dan efisien dapat diaplikasikan oleh masyarakat khususnya produsen pangan.

5. Diperlukan penelitian lebih lanjut dengan lama perendaman lebih dari 3 hari. 


\section{DAFTAR PUSTAKA}

Ardhiyanto, F.,Pawitra, M. dan Sumardiono, S., 2013. Jurnal Teknologi Kimia dan Industri. [online] availabel at: http://ejojurnal-sl. undip. ac.id/index.php/jtki.

Asnawi, R. 2007. Analisis Usahatani Sistem Tanam Double Row Pada Tanaman Ubikayu (Manihot esculenta) di Lampung. Jurnal Pengkajian dan Pengembangan Teknologi Pertanian, Vol.10, No. 1, Juni 2007. Balai Besar Pengkajian dan Pengembangan Teknologi Pertanian, Bogor.

Damanik, B. et al., 2010. Kesuburan Tanah dan Pemupukan. Medan: USU Press

Hambali, E., S. Mujdalipah, A.H. Tambunan, A.W. Pattiwiri, dan R. Hendroko. 2007. Teknologi Bioenergi. Jakarta : Agromedia.

Kartasapoetra, A.G., 2009. Teknologi Konservasi Tanah dan Air. Jakarta: Rineka Cipta.
Sudarmadji, S. et al., 1986. Prosedur Analisa Untuk Bahan Makanan dan Pertanian. Cetakan 1. Yogyakarta: Liberty Yogyakarta.

Sartono., 2002. Racun dan Keracunan. Cetakan 1. Jakarta: Widya Medika.

Suprapti, L., 2005. Tepung Tapioka. 1. Yogyakarta: Kanisius (Anggota IKAPI).

Winarno, F.G., 2004. Kimia Pangan dan Gizi. Jakarta: Gramedia Pustaka Utama.

Widodo, Setiyo, D., 2010. Kimia Analisis Kualitatif. Dasar Penguasaan Aspek Eksperimental. Yogyakarta: Graha Ilmu.

Yuningsih. 2009. Perlakuan penurunan kandungan sianida pada ubi kayu. Jurnal Penelitian Pertanian Tanaman Pangan 28(1):58-6.

http://www.gobookee.org/ebook/penanaman-ubi-kayuofficial-website-of-department-of-gaz6u/ 